\title{
PENDAMPINGAN PEMASARAN DAN PENINGKATAN PENJUALAN MELALUI DARING PADA UD. EVARIO MANDIRI JAYA
}

\author{
1) Evana Andriani ${ }^{2)}$ Faridhatun Faidah, ${ }^{3)}$ Etni Marliana \\ Program Studi Manajemen, Fakultas Ekonomi dan Bisnis, Universitas Muria Kudus \\ Email: ${ }^{1)}$ evana.andriani@umk.ac.id ${ }^{2)}$ faridhatun.faidah@umk.ac.id, ${ }^{3)}$ etni.marliana@umk.ac.id
}

\begin{abstract}
Abstrak
Covid-19 yang saat ini mewabah di seluruh belahan dunia memberikan dampak yang cukup besar untuk perekonomian di Indonesia, khususnya bagi para pengusaha kecil. Keterbatasan modal yang dimiliki, ditambah tingkat penjualan yang menurun drastis, membuat para pengusaha harus berimprovisasi berbagai cara agar produk mereka tetap dapat terjual. Salah satu cara paling efektif untuk meningkatkan penjualan bagi mereka pengusaha kecil yang memiliki modal terbatas, yaitu beralih dari pemasaran dan penjualan secara luring menjadi pemasaran dan penjualan daring. Pemasaran dan penjualan daring dapat dilakukan dengan menggunakan media marketplace maupun sosial media. Tujuan dari pengabdian ini adalah memberikan pendampingan kepada UD. Evario Mandiri Jaya untuk mengembangkan saluran pemasaran dan penjualan dari luring ke saluran pemasaran dan penjualan secara daring, lalu dapat meningkatkan kesadaran merek lebih luas dari para calon konsumennya Setelah kegiatan pengabdian masyarakat ini dilakukan, UD. Evario Mandiri Jaya dapat melaksanakan kegiatan pemasaran dan penjualan secara daring menggunakan marketplace dan media sosial.
\end{abstract}

Kata kunci: marketplace, pemasaran daring, pendampingan, penjualan daring.

\begin{abstract}
The Covid-19, which is currently endemic in all parts of the world, has had a considerable impact on the economy in Indonesia, especially for small entrepreneurs. The limited capital they have, coupled with a drastic drop in sales, have forced entrepreneurs have to improve in various ways to make their products can still be sold. One of the most effective ways to increase sales for those small entrepreneurs who have limited capital is to switch from offline marketing and sales to online marketing and sales. Online marketing and sales can be done using the media marketplace and social media. The purpose of this service is to provide training to UD. Evario Mandiri Jaya to develop marketing and sales channels from offline to online, then can increase brand awareness more broadly from potential consumers After this community service activity was carried out, UD. Evario Mandiri Jaya can start doing marketing and sales activities online using the marketplace and social media.
\end{abstract}

Keywords: marketplace online marketing, online sales, training.

\section{PENDAHULUAN}

Dilansir dari situs www.medcom.id, menurut Deputi Bidang Koordinasi Ekonomi Makro dan Keuangan Kementerian Koordinator Perekonomian Iskandar Simorangkir pertumbuhan ekonomi di Indonesia pada kuartal III tahun 2020 akan mengalami kontraksi dari minus satu persen hingga minus 2,9 persen, angka tersebut lebih dalam dibandingkan proyeksi sebelumnya yang berkisar 1,95 persen (Miftahudin, 2020). Dikatakan bahwa pertumbuhan ekonomi pada kuartal III jauh lebih baik jika dibandingkan pada kuartal II tahun 2020 yang turun hingga minus 5,32 persen (Miftahudin, 2020).

Dampak dari pandemi Covid 19 yang terjadi saat ini tidak hanya berimpas pada sektor makro saja, tetapi pada sektor mikro juga terdampak cukup besar khususnya bagi pelaku 
usaha kecil atau UMKM. UMKM pada tahun 2018 menyumbangkan hingga Rp 8.573,9 triliun ke PDB negara Indonesia dengan prosentase kontribusi sebesar $57,8 \%$ terhadap PDB, dan UMKM menyerap $97 \%$ dari total tenaga kerja dan 99\% dari keseluruhan lapangan kerja dengan jumlah UMKM pada tahun 2018 mencapai sebanyak 64,2 juta unit (Jayani, 2020). Pada tahun 2020 hingga 2024 ditargetkan bahwa UMKM dapat berkontribusi pada perekonomian di Indonesia sebesar $18 \%$ terhadap ekspor di tahun 2020 dan sebesar 30,2\% di tahun 2024. Lalu kontribusi UMKM terhadap PDB nasional 2020 ditargetkan sebesar $61 \%$ dan naik menjadi $65 \%$ pada tahun 2024, sedangkan pada tahun 2020 untuk rasio kewirausahaan ditargetkan 3,55\% dan mencapai 4\% pada tahun 2024 (Nurhaliza, 2020).

Akibat adanya wabah Covid 19 ini, pertumbuhan UMKM menjadi terhambat hingga mengakibatkan penurunan penjualan. Hal ini dikarenakan masyarakat lebih memprioritaskan berbelanja bahan-bahan pokok seperti makanan dibandingkan berbelanja barang-barang lain. Permasalahan lain adalah permodalan yang terbatas, distribusi produk yang terhambat, hingga sulitnya untuk mendapatkan bahan baku dikarenakan banyaknya pemasok yang terpaksa berhenti produksi karena diberlakukannya PSBB dan physical distancing.

Para pengusaha khususnya pelaku UMKM harus memutar otak mencari cara untuk tetap bisa bertahan di tengah kondisi pandemi yang tidak menentu. Dengan adanya pembatasan sosial maka UMKM tidak bisa leluasa untuk berjualan seperti keadaan sebelumnya. Banyak tempat berjualan seperti pasar atau pusat perbelanjaan lainnya yang terpaksa ditutup agar tidak banyak orang berkerumun demi menurunkan angka kasus Covid-19. Maka daripada itu banyak pengusaha yang beralih melakukan penjualan produk mereka dari luring menjadi daring. Para pengusaha bisa memanfaatkan media sosial dan marketplace yang tidak berbayar untuk memasarkan dan menjual produknya secara daring.

Dilansir dari www.cnbcindonesia.com

Menteri Koperasi dan UKM Teten Asduki mengatakan bahwa BI mencatat untuk bulan Mei 2020 penjualan E-commerce meningkat sebanyak $18 \%$. Akan tetapi UMKM yang sudah terhubung dengan marketplace online in baru sebesar 13\% atau sekitar 8 juta lebih pelaku UMKM. Padahal jumlah UMKM di Indonesia saat ini sudah berjumlah sebanyak 64juta lebih pelaku UMKM (Sandi, 2020). Dengan pernyataan tersebut tentunya peluang penjualan secara daring masih terbuka dengan lebar bagi para pelaku UMKM. Apalagi ditambah dengan situasi pandemi saat ini di mana seluruh aktivitas masyarakat dilakukan secara digital dan dari rumah. Hal ini menjadi peluang yang dapat dimanfaatkan oleh pelaku UMKM untuk menjaga bahkan menaikkan penjualannya di tengah masa pandemi.

Banyak marketplace online yang bisa digunakan oleh pelaku UMKM untuk menjual produknya, mulai dari makanan, alat elektronik, hingga produk kecantikan sudah banyak dijual di marketplace yang ada di Indonesia. Salah satu marketplace online di Indonesia adalah Shopee yang memiliki jumlah pengunjung bulanan mencapai 93 juta pelanggan (Niken, 2020). Marketplace lainnya adalah Tokopedia dengan jumlah pengunjung bulanan sebanyak 86 juta pelanggan (Niken, 2020). Kedua marketplace tersebut dapat menjadi pilihan bagi pelaku UMKM untuk memasarkan dan menjual produknya di masa pandemi saat ini.

UMKM selain memanfaatkan penjualan secara daring juga dapat menggunakan media sosial untuk memasarkan produknya. Pada saat ini, pemasaran menggunakan media sosial telah berkembang pesat dan menjadi sarana populer di mana bisnis menjangkau pelanggan potensial. Tujuan dari pendekatan pemasaran baru ini adalah untuk menarik perhatian pengguna dan menyebarkan pesan iklan seluas mungkin melalui media sosial. Menurut Jackson, dkk. (2007) menemukan bahwa saluran media sosial lebih efektif dalam mempengaruhi konsumen daripada saluran pemasaran tradisional.Saat ini banyak media sosial yang digunakan pemasar untuk menginklankan produknya seperti Facebook, Instagram bahkan aplikasi yang sedang digandrungi oleh masyarakat saat ini yaitu Tiktok dengan total unduhan berjumlah lebih dari 30,7 juta pengguna pada Juli 2020 (Rayana, 2020). Dengan berbekal smartphone, para pelaku usaha UMKM bisa mengunggah berbagai konten mengenai produknya di media sosial, dengan harapan bahwa hal tersebut akan meningkatkan brand awareness dari calon konsumen dan 
peningkatan penjualan di masa pandemi saat ini. Dimana merek yang dikenal luas jauh lebih mungkin untuk dipertimbangkan, dan akibatnya dipilih, daripada merek yang tidak dikenal oleh konsumen. Semakin dikenal merek, semakin besar kemungkinan konsumen akan berniat untuk membeli dan merekomendasikan layanan atau produk tersebut (Horn, dkk. 2011). Kesadaran merek mengacu pada "kekuatan kehadiran merek di benak konsumen" (Pappu et al., 2005, hlm.145) dan didefinisikan sebagai "kemampuan pembeli untuk mengenali atau mengingat kembali bahwa suatu merek adalah anggota dari suatu kategori produk" (Aaker, 1991, hlm. 61; Yoo dan Donthu, 2001, hlm. 3) dan dikonseptualisasikan sebagai terdiri dari ingatan dan pengenalan merek (Keller, 1993; Pappu et al., 2005; Rossiter dan Percy, 1987; Yoo dan Donthu, 2001).

Salah satu UKM yang mengalami banyak penurunan penjualan selama pandemi adalah UD. Evario Mandiri Jaya yang berlokasi di Desa Wangunrejo Kecamatan Margorejo Kabupaten Pati. Perusahaan ini merupakan perusahaan yang memproduksi kaos kaki. Selama ini produknya dipasarkan secara langsung melalui toko-toko distributor yang berlokasi di Kudus Jawa Tengah. Namun, selama pandemi, penjualan produk dari UD. Evario Mandiri Jaya khususnya kaos kaki untuk siswa SD, SMP, SMA mengalami penurunan. Hal tersebut diakibatkan karena kegiatan belajar mengajar yang dilakukan secara daring, sehingga membuat para siswa tidak harus ke sekolah untuk mengikuti kegiatan belajar mengajar, dan pada akhirnya memberikan dampak penurunan pembelian produk kaos kaki pada UD. Evario Mandiri Jaya. Penurunan penjualan juga diakibatkan karena selama ini kegiatan pemasaran dan penjualan produk kaos kaki UD. Evario Mandiri Jaya masih mengandalkan pemasaran dan penjualan secara luring, dan belum melakukan secara daring.

\section{METODE PENGABDIAN}

Kegiatan pengabdian dilaksanakan secara langsung pada lokasi UD. Evario Mandiri Jaya, dengan tetap memperhatikan protokol kesehatan yang berlaku. Pelaksanaan pengabdian dilaksanakan secara langsung bukan melalui daring, karena dirasa pemaparan materi yang diberikan perlu dipaparkan dan disimulasikan secara langsung.

Adapun metode yang digunakan dalam kegiatan pengabdian kepada masyarakat adalah sebagai berikut:

1. Ceramah

Peserta diberikan pemaparan mengenai pemasaran produk melalui media sosial dan penjualan produk menggunakan online marketplace, yang disampaikan oleh masingmasing anggota tim pengabdian.

2. Simulasi

Peserta melakukan pembuatan account pada sosial media dan marketplace dan tim pengabdian mendampingi peserta dalam pembuatan akun tersebut.

3. Diskusi dan tanya jawab

Diskusi dan tanya jawab dilakukan setelah pemaparan materi dan simulasi selesai dijalankan untuk mengetahui seberapa jauh pemahaman peserta akan materi yang dipaparkan oleh tim anggota pengabdian.

\section{HASIL DAN PEMBAHASAN}

Kegiatan ini dilakukan dalam lima tahapan. Tahapan pertama adalah perencanaan kegiatan. Tahap kedua merupakan tahap pelaksanaan kegiatan. Tahap ketiga adalah tahap follow up kegiatan pelatihan pendampingan penggunaan media sosial dan marketplace. Tahap keempat adalah yaitu simulasi dan praktek. Tahapan yang terakhir adalah evaluasi kegiatan.

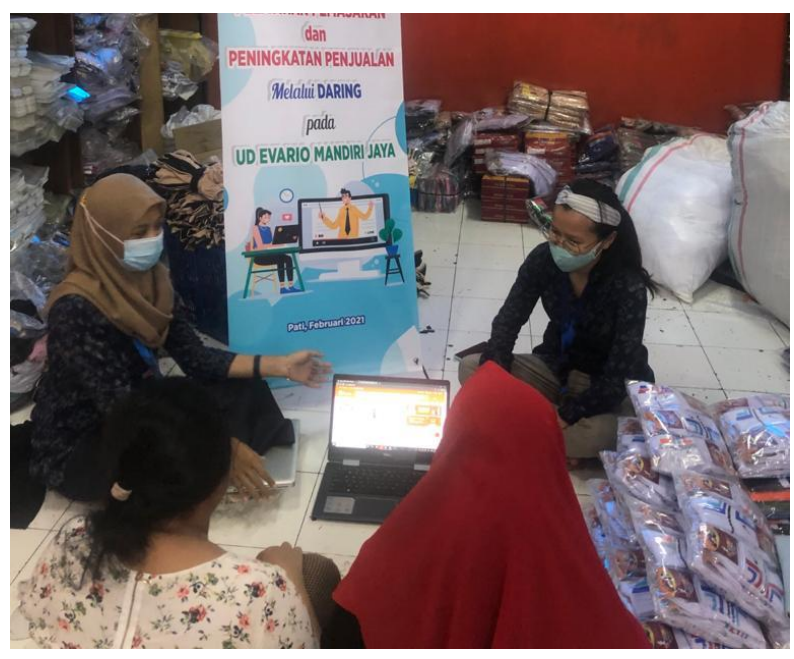

Gambar 1. Proses pendampingan 


\section{Tahap Perencanaan Kegiatan}

Pada tahapan ini tim pengabdian melakukan perencanaan untuk menjalankan program pengabdian. Perencanaan diawali yaitu komunikasi awal dengan UD. Evario Mandiri Jaya. Komunikasi dilanjutkan dengan studi lapangan dan berkoordinasi dengan pemilik UD. Evario Mandiri Jaya untuk menganalisis situasi dan juga permasalahan yang terjadi, utamanya berkaitan dengan penurunan penjualan kaos kaki akibat pandemi Covid-19. Dari studi lapangan didapatkan hasil bahwa UD. Evario Mandiri Jaya belum pernah melakukan kegiatan pemasaran dan penjualan secara daring. Setelah itu, tim pengabdian kemudian merencanakan materi yang akan diberikan sebagai solusi atas permasalahan yang dihadapi UD. Evario Mandiri Jaya. Pembuatan materi juga mengacu pada sumber rujukan dan literatur terkait dengan pemasaran dan penjualan secara daring. Gambar 1. Merupakan pemaparan mengenai pemasaran dan penjualan secara daring dan dampak dari pemanfaatan tersebut pada pemasaran dan penjualan produk dari UD. Evario Mandiri Jaya kedepannya.

\section{Tahap Pelaksanaan}

Kegiatan pengabdian ini dilaksanakan dengan cara melakukan pemaparan terkait pemasaran dan penjualan secara daring kepada pemilik dan karyawan UD. Evario Mandiri Jaya.

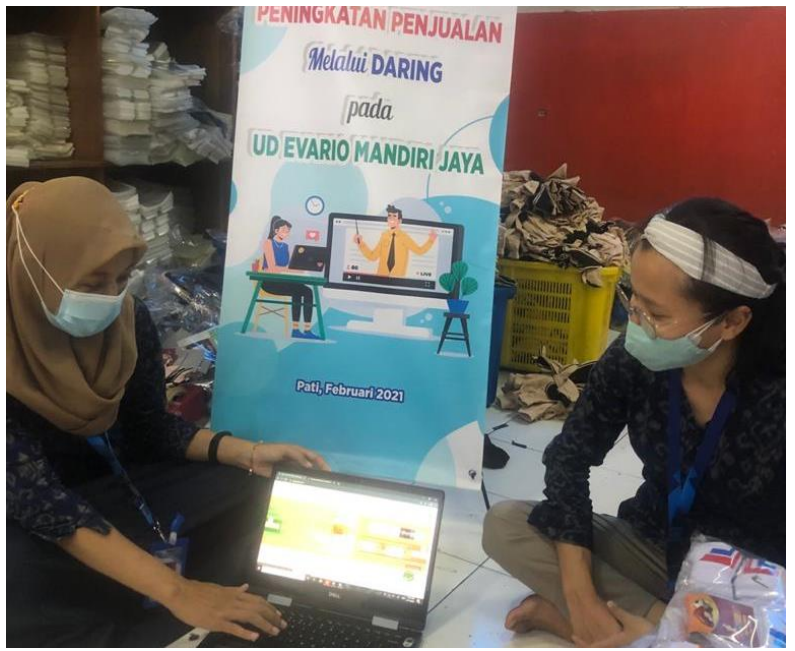

Gambar 2. Pemaparan mengenai pemasaran dan penjualan secara daring menggunakan marketplace pada produk UD. Evario Mandiri Jaya
Paparan pertama adalah mengenai pemasaran secara daring serta dampaknya bagi pemasaran dan penjualan produk dari UD. Evario Mandiri Jaya kedepannya. Selain itu diberikan juga pemaparan yang lebih spesifik terkait dengan penjualan daring menggunakan media sosial dan juga online marketplace yang bisa dimanfaatkan UD. Evario Mandiri Jaya untuk menyalurkan produknya kepada konsumen yang selama ini masih dilakukan secara offline.

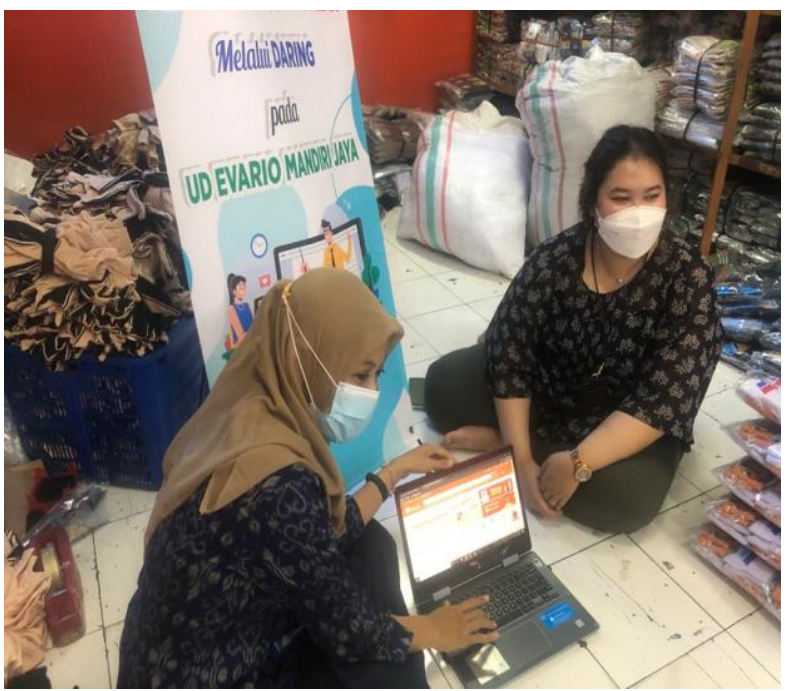

Gambar 3. Pemaparan mengenai pemasaran dan penjualan secara daring menggunakan media sosial pada produk UD. Evario Mandiri Jaya

Tahapan ini juga menjelaskan pentingnya untuk memperkenalkan produk kaos kaki UD. Evario Mandiri Jaya secara online agar lebih banyak orang yang mengetahui produk tersebut. Melalui media online, produk kaos kaki bisa diperkenalkan dan dijual kepada lebih banyak calon konsumen yang berasal dari segmen para pegawai kantoran, wanita berhijab, maupun atlit tanpa harus bertemu dengan mereka. Dengan demikian, walaupun permintaan kaos kaki untuk pasar anak sekolah berkurang, dimungkinkan bisa muncul permintaan dari segmen konsumen lain melalui media pemasaran online.

\section{Tahap Follow Up Kegiatan Pelatihan}

Tahap follow up kegiatan pelatihan pendampingan kepada staff/karyawan dari UD. Evario Mandiri Jaya. Kegiatan pendampingan dilakukan dalam bentuk pendampingan praktek 
pembuatan akun sosial media dan marketplace. Selain itu juga diberikan penjelasan alur proses dari pemasaran dan penjualan menggunakan sosial media dan marketplace.

\section{Tahap Praktek dan Simulasi}

Pada tahap praktek dan simulasi, peserta sosialisasi melakukan praktek pembuatan akun pada media sosial Instagram. Berikut langkahlangkah untuk membuat akun instagram bisnis:

a. Cara mendaftar Instagram yaitu dengan mengunduh aplikasinya secara gratis dari App Store untuk pengguna iPhone dan Google Play Store bagi pengguna Android.

b. Mengklik pilihan Daftar dengan Email atau Nomor Telepon. Kemudian masukkan alamat email atau nomor telepon pada kolom isian yang tersedia.

c. Langkah berikutnya dalam cara daftar Instagram adalah membuat nama pengguna dan kata sandi yang akan digunakan untuk akun tersebut, dan lakukan edit profil untuk menambahkan atau mengganti informasi terkait dengan akun tersebut.

d. Setelah masuk pada profil, kemudian mengklik Pengaturan/Setting. Pilihan ini ada pada pojok kanan atas profil. Lalu diklik account.

e. Lalu mengubah akun menjadi Instagram menjadi akun Instagram bisnis dengan klik pilihan switch to business account. Klik continue, lalu pilih jenis bisnis yang dijalankan.

f. Setelah itu mengklik klik next atau lanjutkan. Akan diminta untuk melakukan konfirmasi apakah alamat email dan nomor telepon yang dicantumkan sudah sesuai atau belum. Hal ini untuk memudahkan calon pembeli menghubungi untuk melakukan aktivitas transaksi.

g. Lalu mengunggah foto atau video terkait dengan produk, dan menyertakan caption untuk menarik calon konsumen

Pada tahap praktek dan simulasi, peserta sosialisasi melakukan praktek pembuatan account pada marketplace Shopee dan Tokopedia. Langkah-langkah untuk membuat account marketplace Shopee dan Tokopedia bisa diakses pada laman berikut: a. Shopee:

https://seller.shopee.co.id/edu/article/464

b. Tokopedia:

https://seller.tokopedia.com/edu/mulaiberjualan/

\section{Tahap Evaluasi Kegiatan}

Di akhir kegiatan, kegiatan tanya jawab dan diskusi antara peserta dengan pemateri. Dalam tahap ini, peserta diberi kesempatan untuk bertanya dan memberikan tanggapan terhadap materi pelatihan pemasaran dan peningkatan penjualan melalui daring yang telah dijelaskan oleh tim pengabdian. Hal ini dilakukan sebagai bentuk evaluasi apakah peserta mengerti materi yang diberikan oleh tim pengabdian atau tidak. Tim pengabdian juga bertanya beberapa hal kepada peserta pelatihan untuk mendapatkan masukan dan menggali apakah kegiatan pengabdian memberikan manfaat bagi peserta pengabdian secara efektif. Evaluasi dilakukan dengan cara studi lapangan kembali dan berkomunikasi dengan pemilik usaha dari UD. Evario Mandiri Jaya setelah kegiatan pengabdian dilaksanakan. Dari hasil evaluasi diperoleh informasi bahwa kegiatan pengabdian berupa pendampingan pemasaran dan peningkatan penjualan secara daring pada UD. Evario Mandiri Jaya dapat diikuti peserta dengan baik dan sudah mulai diimplementasikan atau dilaksanakannya pemasaran dan penjualan secara daring. Terjadi peningkatan penjualan produk secara daring, walaupun belum berkontribusi besar pada total penjualan secara keseluruhan, di mana masih di dominasi oleh penjualan secara luring dikarenakan kegiatan pemaran dan penjualan secara daring masih pada tahap awal atau baru untuk UD. Evario Mandiri Jaya.

\section{PENUTUP \\ Kesimpulan}

Staff/karyawan pada UD. Evario Mandiri Jaya memiliki kemauan yang tinggi untuk mempelajari hal baru, termasuk dalam belajar memanfaatkan media sosial dan marketplace untuk mempromosikan serta menjual produk kaos kaki yang dihasilkan UKM ini. Selama ini UD. Evario Mandiri Jaya sudah melakukan berbagai kegiatan pemasaran dan penjualan secara tradisional, akan tetapi tingkat hasil penjualan 
yang didapatkan masih terbatas. Hal tersebut terjadi dikarenakan cara pemasaran dan penjualan yang masih konvensional atau tradisional dan masih mengandalkan rekomendasi merek dari mulut ke mulut.

Dengan diadakannya kegiatan pengabdian terkait dengan cara pemasaran dan penjualan secara daring, hal ini secara khusus dapat memberikan perubahan pada pola pemasaran dan penjualan dari konvensional menjadi daring pada UD. Evario Mandiri Jaya. Melalui pelatihan ini diharapkan UD. Evario Mandiri Jaya bisa mulai menggunakan media sosial dan online marketplace sehingga penjualan dan kesadaran merek akan mengingkat. Dengan demikian, pendapatan dari UD. Evario Mandiri Jaya yang telah menurun selama pandemi Covid-19 berlangsung diharapkan bisa meningkat.

\section{Saran}

Dengan telah dilaksanakannya sosialisasi dan pelatihan pemasaran dan penjualan secara daring pada UD. Evario Mandiri Jaya, diharapkan staff/karyawan yang menjadi peserta pelatihan dapat mengembangkan kemampuan dalam pemanfaatan media daring untuk peningkatan kesadaran merek dan peningkatan penjualan produk. Dengan demikian, kegiatan pemasaran dan penjualan produk dari UKM ini dapat berlangsung dengan lebih efektif dan efisien dengan adanya pemanfaatan media daring yang digunakan di kemudian hari.

\section{DAFTAR PUSTAKA}

Aaker, D.A., (1991). Managing Brand Equity. The Free Press, NY.

Dabbous, A., Barakat, K.A. (2020). Bridging the online of ine gap: Assessing the impact of brands' social network content quality on brand awareness and purchase intention. Journal of Retailing and Consumer Service, 53.

Horng, J. S., Liu, C. H., Chou, H. Y., \& Tsai, C, C.Y. (2011) Understanding the impact of culinary brand equity and destination familiarity on tranvel intentions. Tourism Management, 33(4), 815-824.

Jackson, A., Yates, J., Orlikowski, W. (2007) Corporate Blogging: Building Community
Through Persistent Digital Talk. Proceeding of the $40^{\text {th }}$ Annual Hawaii International Conference on System Sciences, 80.

Jayani, D.H. (2020). Berapa Sumbangan UMKM Terhadap Perekonomian Indonesia. Tersedia di https://databoks.katadata.co.id/datapublish /2020/05/20/berapa-sumbangan-umkmterhadap-perekonomian-indonesia, diakses pada 18 Oktober 2020.

Keller, K.L. (1993). Conceptualizing, measuring, and managing customer-based brand equity. Journal of Marketing, 57 (January), 1-22.

Maier, E., Wieringa, J. (2020). Acquiring Customers through Online Marketplaces? The Effect of Marketplace Sales on Sales in a Retailer's own Channels. International Journal of Research in Marketing.

Miftahudin, H. (2020). Ekonomi RI Kuartal III2020 Bakal Terkontraksi hingga Minus 2,9\%. Tersedia di https://www.medcom.id/ekonomi/makro/o b33JL5b-ekonomi-ri-kuartal-iii-2020-

bakal-terkontraksi-hingga-minus-2-

9\#: :text=perekonomian\%20Ekonomi\%20 Indonesia-

,Ekonomi\%20RI\%20Kuartal\%20III\%2D2 020,Terkontraksi\%20hingga\%20Minus\%2 02\%2C9\%25\&text=Jakarta\%3A\%20Depu ti\%20Bidang\%20Koordinasi\%20Ekonomi ,persen\%20hingga\%202\%2C9\%20persen, diakses pada 18 Oktober 2020.

Niken, G. (2020). Daftar Marketplace Indonesia 2020 Dengan Kunjungan Terbanyak. Tersedia di https://ajaib.co.id/daftarmarketplace-indonesia-2020-dengankunjungan-terbanyak/, diakses pada 18 Oktober 2020.

Nurhaliza, S. (2020). Ini Target UMKM Terhadap Ekonomi di 2020-2024. Tersedia di https://www.idxchannel.com/marketnews/ini-target-kontribusi-umkmterhadap-ekonomi-di-2020-2024, diakses pada 18 Oktober 2020.

Pappu, R., Quester, P.G., Cooksey, R.W. (2005). Consumer-based brand equity: improving the measurement-empirical evidence. 
Journal of Product and Brand Management, 14(3), 143-154.

Rayana, U. (2020). Meski Indonesia Salah Satu Pengguna Tiktok Terbesar, ByteDance Pilih Singapura Sebagai Sasaran Investasi. Tersedia https://selular.id/2020/09/meski-indonesiasalah-satu-pengguna-tiktok-terbesarbytedance-pilih-singapura-sebagaisasaraninvestasi/\#: :text=Dengan\%20total\%20un duhan $\% 208 \% 2 \mathrm{C} 5$,juta\%20pengguna\%20T ikTok\%20di\%20Indonesia, diakses pada 18 Oktober 2020.

Rositter, J. R., Percy, L. (1987). Advertising and Promotion Management. McGraw-Hill Book Company, NY.

Sandi, F. (2020). Baru 13\% UMKM di RI yang Melek Digital. Tersedia di https://www.cnbcindonesia.com/news/202 00629190231-4-168897/baru-13-umkmdi-ri-yang-melek-digital, diakses pada 18 Oktober 2020.

Yoo, B., Donthu, N. (2001). Developing and validating a multidimensional consumerbased brand equity scale. Journal of Business Research, 52 (1), 1-14. 